\title{
Upaya Meningkatkan Kosakata Bahasa Inggris Pada Anak Usia Dini Dengan Media Wayang Melalui Video Pembelajaran
}

\section{Ni Putu Gita Oktapiani ${ }^{1}$, Nice Maylani Asril ${ }^{2}$, Dewa Gede Firstia Wirabrata ${ }^{3}$}

1,2,3 Jurusan Pendidikan Guru Pendidikan Anak Usia Dini, STKIP Modern, Ngawi, Indonesia

\section{A R T I C L E I N F O}

Article history:

Received 27 April 2021

Revised 28 April 2021

Accepted 01 Juli 2021

Available online 25 Agustus 2021

Kata Kunci:

Kemampuan Kosakata, Media

Wayang, Video

Keywords:

Vocabulary Skills, Puppet Media

Video

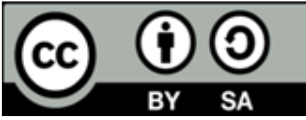

This is an open access article under the CC BY-SA license.

Copyright (@) 2021 by Author. Published by Universitas Pendidikan Ganesha.

\begin{abstract}
A B S T R A K
Permasalahan yang terjadi saat ini yaitu masih banyak anak yang memiliki kemampuan bahasa yang rendah. Kurangnya media pembelajaran yang dapat memfasilitasi anak dalam belajar, berdampak pada hasil belajar anak yang rendah. Penelitian ini bertujuan untuk menciptakan media wayang melalui video pembelajaran pada anak usia dini. Jenis penelitian ini adalah penelitian pengembangan dengan model yang digunakan yaitu ADDIE. Subjek pada penelitian ini yaitu 2 orang ahli media pembelajaran dan 2 orang ahli materi pelajaran. Metode yang digunakan dalam mengumpulkan data yaitu wawancara, dokumentasi, dan kuesioner. Instrumen yang digunakan dalam mengumpulkan data yaitu kuesioner. Analisis yang digunakan dalam penelitian ini adalah analisis statistik kualitatif dan statistik kuantitatif. Hasil penelitian yaitu hasil uji dari ahli isi mata pelajaran dan ahli media pembelajaran mendapatkan nilai 1,00 sehingga berada pada kualifikasi sangat tinggi. Jadi media yang dikembangkan berupa media wayang melalui video pembelajaran dapat diterapkan dalam pembelajaran untuk anak usia dini. Implikasi penelitian ini yaitu media wayang melalui video pembelajaran dapat memudahkan anak usia dini dalam belajar sehingga dapat meningkatkan kosakata bahasa Inggris pada anak usia dini.
\end{abstract}

\begin{abstract}
A BS TRACT
The problem that occurs today is that there are still many children who have low language skills. The lack of learning media that can facilitate children in learning, has an impact on children's low learning outcomes. This study aims to develop wayang media through learning videos for early childhood. This type of research is development research with the model used is ADDIE. The subjects in this study were 2 learning media experts and 2 subject matter experts. The methods used in collecting data are interviews, documentation, and questionnaires. The instrument used in collecting data is a questionnaire. The analysis used in this study is a qualitative statistical analysis and quantitative statistics. The results of the study, namely the test results from subject content experts and learning media experts got a score of 1.00 so that they were in a very high qualification. So the media developed in the form of puppet media through learning videos can be applied in learning for early childhood. The implication of this research is that puppet media through learning videos can facilitate early childhood in learning so that they can increase English vocabulary in early childhood.
\end{abstract}

\section{PENDAHULUAN}

Pendidikan memiliki peran yang sangat penting dalam membangun bangsa dan negara kearah yang lebih maju. Tujuan pendidikan yaitu dapat mengembangkan seluruh potensi yang ada pada diri manusia serta keterampilan yang dapat digunakan nantinya (Prameswari, 2018; Sari, 2014; Widodo, 2016). Pendidikan formal yang paling pertama didapatkan oleh seseorang yaitu pendidikan anak usia dini. Pendidikan anak usia dini sangat penting sebagai dasar pembentukan kepribadian anak secara utuh yang meliputi pembentukan kecerdasan, karakter, dan budi pekerti (Dewi et al., 2018; Dista, 2020; Yuniarni et al., 2020). Pada pendidikan anak usia dini beberapa aspek yang dikembangkan yaitu motorik, kognitif, bahasa, dan sosial emosional serta seni (Marini, 2015; Poerwati \& Cahaya, 2018). Aspek tersebut perlu dirangsang sehingga anak usia dini dapat mencapai perkembangan yang optimal. Melalui pendidikan maka akan menumbuh kembangkan potensi anak, sehingga anak memiliki kesiapan ketika memasuki sekolah dasar (Aisyah, 2017; Iswantiningtyas \& Wulansari, 2018; Sari \& Setiawan, 2012). Hal tersebut 
yang menyebabkan pendidikan usia dini sangat penting diberikan. Pada masa ini akan mengalami masa keemasan (golden age) sehingga mengalami perkembangan yang begitu cepat. Lingkup perkembangan anak usia dini mencakup beberapa aspek yaitu kognitif, fisik motorik, sosial, nilai agama dan moral, seni dan bahasa (Pebri et al., 2017; Swastrini et al., 2016). Dari seluruh aspek perkembangan, bahasa termasuk perkembangan yang paling penting bagi pertumbuhan anak usia dini sehingga aspek ini perlu diperhatikan.

Permasalahan yang terjadi saat ini yaitu masih banyak anak yang memiliki kemampuan bahasa yang rendah (Kurnia et al., 2018; Resti Aulia \& Budiningsih, 2021). Padahal bahasa sangat diperlukan dalam kehidupan sehari-hari karena bahasa merupakan alat komunikasi bagi anak. Selain itu pembelajaran bilingual sesungguhnya wajib dilaksanakan untuk menguatkan kemampuan anak dalam berbahasa asing. Permasalahan ini juga terjadi di salah satu taman kanak-kanak. Berdasarkan hasil observasi yang dilakukan di TKK Santo Yusup Bangli. Ditemukan permasalahan yaitu kemampuan anak dalam menambah kosakata bahasa Inggris masih belum maksimal. Dilihat dari cara guru dalam melaksanakan proses pembelajaran yang berpusat pada guru, serta dalam pemilihan media belum bervariasi, metode yang digunakan dalam pembelajaran masih sangat monoton (menggunakan metode konvensional), sehingga anak-anak cepat merasa bosan dalam proses pembelajaran. Pembelajaran yang bersifat monotun membuat anak menjadi bosan dalam belajar (P. K. Putri et al., 2020; Umbara et al., 2020; Widnyana et al., 2017). Berdasarkan hasil observasi, anak-anak yang dapat memahami apa yang disampaikan oleh guru hanya beberapa anak saja yang lain hanya diam melihat temannya menjawab. Hal tersebut berdampak pada pemahaman anak terhadap bahasa asing yang rendah. Jika hal ini dibiarkan maka akan berpengaruh kepada kemampuan berbahasa asing pada anak usia dini yang rendah.

Berdasarkan permasalahan tersebut, maka salah satu solusi yang dapat digunakan untuk mengatasi permasalahan tersebut dengan mengembangkan media pembelajaran inovatif yang dapat meningkatkan kemampuan bahasa pada anak usia dini. Media pembelajaran merupakan sarana belajar yang dapat memudahkan siswa dalam belajar (Gunawan et al., 2017; Stoica \& Roco, 2013; Sunismi, 2015; Yusnia, 2019). Media pembelajaran inovatif dan sesuai dengan karakteristik siswa dapat meningkatkan semangat serta motivasi siswa dalam belajar (Melianti, 2020; Moll-Khosrawi et al., 2021; Mutakinati et al., 2018). Media pembelajaran sangat penting untuk meningkatkan semangat belajar pada anak usia dini. Berbagai variasi media pembelajaran akan memiliki dampak atau pengaruh pada anak usia dini (Hardiyanti et al., 2018; Marini, 2015). Media pembelajaran dapat memudahkan siswa dalam memahami materi pembelajaran yang disampaikan oleh guru. Salah satu media pembelajaran inovatif yang dapat dikembangkan untuk meningkatkan kemampuan kosakata bahasa inggris pada anak yaitu media wayang melalui video pembelajaran. Wayang merupakan gambaran budaya Jawa yang memberikan pesan mengenai filsafat kehidupan. Selain itu wayang juga mengandung nilai seni (Nababan, 2016; Suprihatin \& Pratamawati, 2019). Pengembangan video wayang akan meningkatkan semangat siswa dalam belajar terutama belajar kosakata Bahasa Inggris. Video pembelajaran merupakan media pembelajaran yang memadukan unsur audio dan visual dalam menyalurkan sebuah informasi (Pramana et al., 2016; Sudiarta \& Sadra, 2016; Susmiati, 2020). Video pembelajaran akan dapat memfasilitasi belajar anak baik yang memiliki gaya belajar audio maupun gaya belajar visual. Video pembelajaran yang dikemas dengan baik akan memudahkan anak dalam memahami materi pembelajaran (Heo \& Toomey, 2020; Tegeh et al., 2019; Yusnia, 2019). Melalui video pembelajaran ini anak usia dini akan lebih tertarik untuk belajar kosakata bahasa Inggris dibandingkan dengan pembelajaran dengan metode yang konvensional.

Temuan penelitian sebelumnya mengenai video pembelajaran menyatakan bahwa video pembelajaran dapat meningkatkan hasil belajar siswa secara signifikan (Andriyani \& Suniasih, 2021; Naharir \& Dantes, 2019; Yuniarni et al., 2020). Temuan penelitian lainnya yaitu media video pembelajaran dapat meningkatkan semangat serta motivasi anak usia dini dalam belajar (Darihastining et al., 2020; Yuliani et al., 2017). Kelemahan penelitian sebelumnya yaitu video pembelajaran yang dibuat memiliki durasi yang terlalu panjang sehingga konsentrasi kurang maksimal. Selain itu, belum adanya kajian mengenai media wayang melalui video pembelajaran pada anak usia dini. Kelebihan media yang dikembangkan yaitu video yang dikembangkan menggunakan media wayang sehingga juga dapat mengajarkan seni Indonesia. Selain itu media ini disajikan sesuai dengan karakteristik siswa sehingga dapat meningkatkan pemahaman siswa dalam belajar kosakata bahasa Inggris. Pada video juga disajikan dengan durasi yang singkat sehingga konsentrasi anak akan tetap terjaga. Tujuan penelitian ini yaitu untuk menciptakan media wayang melalui video pembelajaran pada anak usia dini. Diharapkan video pembelajaran yang dikembangkan dapat memotivasi siswa dalam belajar sehingga dapat meningkatkan kosakata Bahasa Inggris pada anak usia dini. 


\section{METODE}

Jenis penelitian ini yaitu penelitian pengembangan (Research and Development). Model yang digunakan pada penelitian ini yaitu ADDIE memiliki 5 tahapan yang meliputi tahapan analysis, design, development, implementation, evaluation (Darmayasa, et al 2018). Adapun desain penelitian disajikan pada gambar 1.

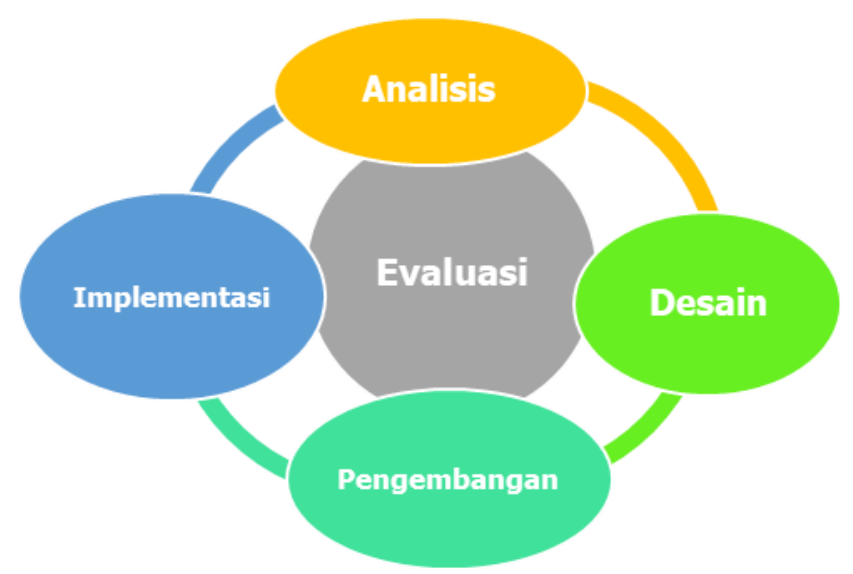

Gambar 1. Rancangan penelitian dengan Model ADDIE (Darmayasa, et al 2018).

Pemilihan model ADDIE ini dikarenakan alur pada model ini bersifat sistematis dan sangat mudah untuk dimengerti. Subyek penelitian ini berjumlah 4 orang ahli yaitu 2 orang ahli media pembelajaran dan 2 orang ahli materi pelajaran. Teknik yang digunakan dalam mengumpulkan data pada penelitian ini yaitu wawancara, kuesioner, dan dokumentasi. Wawancara digunakan untuk mengetahui masalah yang dihadapi oleh guru maupun anak usia dini. Metode kuesioner digunakan untuk mengetahui validitas media yang akan dikembangkan. Dokumentasi digunakan sebagai bukti hasil penelitian. Instrument yang digunakan dalam mengumpulkan data yaitu kuesioner. Kisi-kisi instrumen yang dikembangkan disajikan pada tabel berikut.

Tabel 1. Kisi-Kisi Instrumen untuk Uji Ahli Materi Pelajaran

\begin{tabular}{|c|c|c|}
\hline No & Dimensi & Indikator \\
\hline 1. & Isi materi & $\begin{array}{l}\text { 1. Media wayang melalui video pembelajaran sesuai untuk } \\
\text { mendukung pembelajaran kosakata bahasa Inggris anak } \\
\text { 2. Kesesuaian materi Media wayang melalui video pembelajaran } \\
\text { dengan tingkat pengetahuan kosakata bahasa Inggris anak }\end{array}$ \\
\hline 2. & Kejelasan Materi & 3. Kejelasan materi pada gambar \\
\hline 3. & Kurikulum & $\begin{array}{l}\text { 4. Kesesuaian materi Media wayang melalui video pembelajaran } \\
\text { dengan tingkat pengetahuan kosakata bahasa Inggris anak }\end{array}$ \\
\hline 4 & Tujuan & $\begin{array}{l}\text { 5. Kesesuaian Media wayang melalui video pembelajaran untuk } \\
\text { meningkatkan pengetahuan kosakata bahasa Inggris anak }\end{array}$ \\
\hline 5 & Bahasa & 6. Bahasa yang digunakan sederhana dan mudah dipahami \\
\hline 6 & Motivasi & 7. Kesesuaian Materi dapat memotivasi belajar anak \\
\hline
\end{tabular}

(Susmiati, 2020)

Tabel 2. Kisi-Kisi Instrumen untuk Uji Ahli Media Pelajaran

\begin{tabular}{ccll}
\hline No & Dimensi & & \multicolumn{1}{c}{ Indikator } \\
\hline 1. & Estetika & 1. & Kemenarikan media wayang melalui video pembelajaran \\
& & 2. & Kesesuaian kosakata yang digunakan \\
& 3. & Kemenarikan media wayang \\
& 4. & Kesesuaian ukuran gambar wayang \\
2. Teknik & 5. & Media dapat digunakan dalam jangka panajang \\
& 6. & Kemudahan penggunaan produk media wayang melalui \\
& & 7. & video pembelajaran \\
& 8. & Produk memiliki keawetan yang baik \\
&
\end{tabular}


Uji validitas instrumen dilakukan untuk mengetahui kelayakan instrumen yang akan digunakan pada penelitian. Pengukuran validitas dalam penelitian ini menggunakan rumus Gregory. Analisis yang digunakan dalam penelitian ini adalah analisis statistik kualitatif dan statistik kuantitatif. Statistik kualitatif untuk mengolah data berupa review ahli, kritik dan saran. Hasil review kemudian dianalisis dengan mengelompokkan data kualitatif yang berupa saran dan komentar. Validitas media wayang melalui video pembelajaran dianalisis dengan menggunakan rumus Content Validity Ratio (CVR).

\section{HASIL DAN PEMBAHASAN}

\section{Hasil}

Tahapan pengembangan media wayang melalui video pembelajaran pada anak usia dini menggunakan model pengembangan ADDIE. Adapun prosesur pengembangan mengembangkan media wayang melalui video pembelajaran pada anak usia dini dimulai pada tahap analisis, desain, pengembangan, implementasi, dan evaluasi. Pemaparan hasil dari setiap tahapan pengembangan akan disajikan sebagai berikut. Tahap pertama yaitu analisis. Pada tahap analisis yang dilaksanakan yakni menganalisis kebutuhan anak dan analisis media. Berdasarkan hasil analisis ditemukan bahwa kemampuan kosakata anak masih kurang. Selain itu kurangnya media pembelajaran yang dapat memfasilitasi anak secara mandiri. Dari hasil observasi dan wawancara kepada kepala sekolah diketahui adanya masalah pada media pembelajaran yang kurang variatif untuk meningkatkan pengetahuan kosakata bahasa Inggris anak. Sehingga masih banyak anak yang belum mengetahui kosakata bahasa inggris. Dengan demikian produk yang akan dikembangkan oleh peneliti diharapkan dapat memenuhi kebutuhan pembelajaran anak. Selanjutnya hasil analisis dapat dirancang dengan menggunakan media wayang melalui video pembelajaran untuk meningkatkan pengetahuan kosakata bahasa Inggris anak di TKK Santo Yusup Bangli.

Tahap kedua yaitu desain. Pada tahap ini dilakukan perancangan media wayang melalui video pembelajaran berdasarkan analisis yang dilakukan. Desain pembuatan media yaitu dengan membuat media wayang dengan kertas karton yang di potong sesuai dengan gambar binatang yang ada dalam tokoh cerita pelangi, gotong royong, gajah yang lapar, raja singa dan jerapah yang sombong. Kemudian membuat video wayang sesuai dengan alur cerita, selanjutnya proses mengedit video menggunakan aplikasi powerdirector. Adapun alat dan bahan yang digunakan dalam pembuatan media wayang melalui video pembelajaran yaitu, kertas karton, gunting, cat minyak, lem, tusuk sate, karet gelang, pensil, kain hijau, benang, handphone untuk merekam dan laptop untuk edit video. Adapun desain media papercraft yang akan dikembangkan tersaji pada gambar 1.

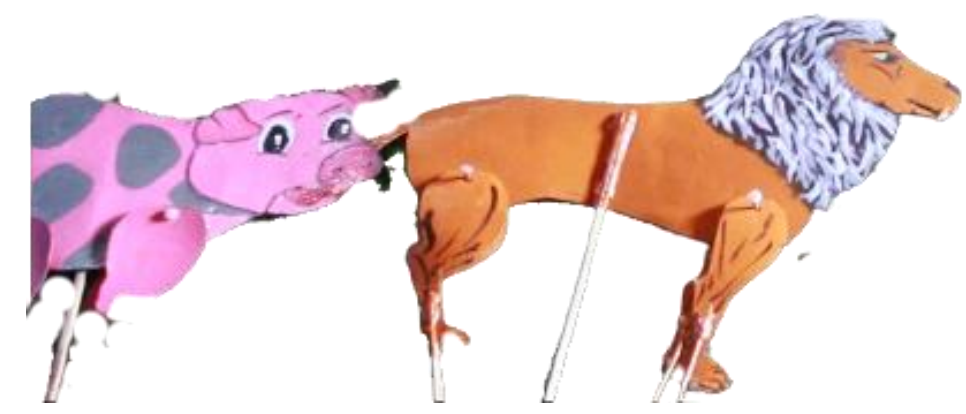

Gambar 1. Rancangan Media Wayang Melalui Video Pembelajaran

Tahap ketiga yaitu pengembangan. Pada tahap ini pelaksanaan pengembangan media disesuaikan dengan rancangan yang telah dibuat. Adapun hasil pengembangan media wayang melalui video pembelajaran tersaji pada gambar 2 . 


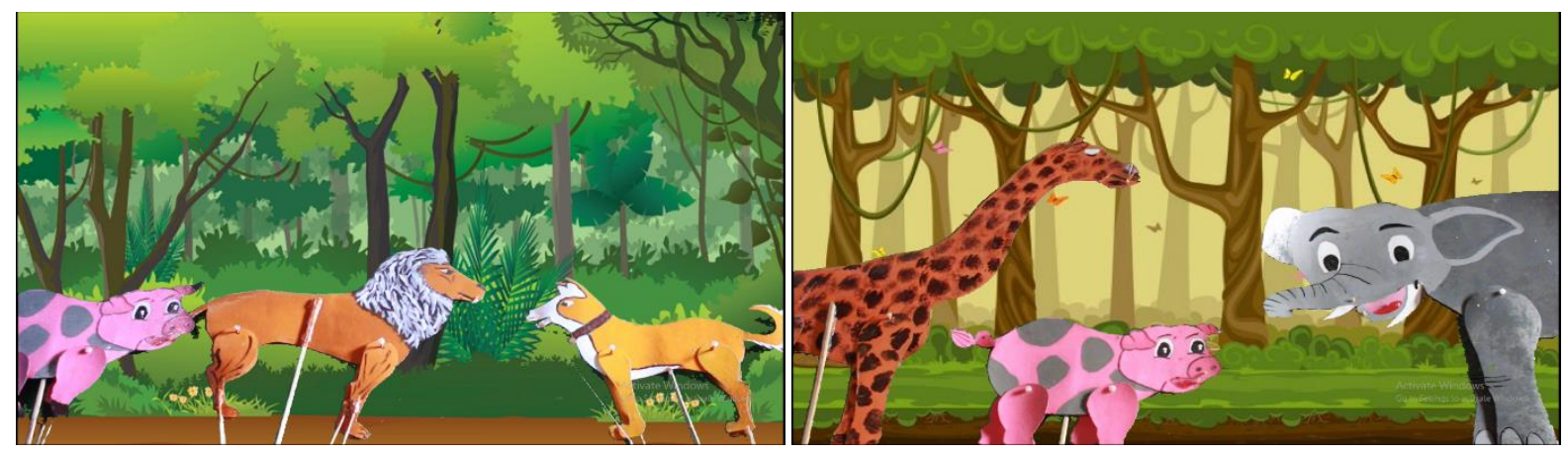

Gambar 2. Rancangan Media Wayang Melalui Video Pembelajaran

Setelah media wayang melalui video pembelajaran dikembangkan, selanjutnya yaitu media wayang melalui video pembelajaran diuji validitasnya oleh ahli isi pelajaran dan media pembelajaran. Berdasarkan hasil uji dari ahli isi mata pelajaran, media yang dikembangkan berupa Media Wayang Melalui Video Pembelajaran mendapatkan hasil validitas yaitu 1,00 sehingga mendapatkan kriteria sangat tinggi. Dapat disimpulkan bahwa materi pada video valid dan layak diterapkan pada anak usia dini. Hasil uji dari ahli media pembelajaran yaitu media yang dikembangkan berupa media wayang melalui video pembelajaran mendapatkan hasil validitas 1,00 maka dapat disimpulkan bahwa media tersebut valid dan mendapatkan kategori sangat tinggi sehingga layak diterapkan pada anak usia dini. Media Wayang Melalui Video Pembelajaran mendapatkan kategori sangat tinggi sehingga tidak ada saran dari para ahli materi ataupun media pembelajaran untuk merevisi produk. Dapat disimpulkan bahwa media pembelajaran berupa media wayang melalui video pembelajaran yang dikembangkan layak diterapkan dalam proses pembelajaran. Hal ini dikarenakan oleh beberapa faktor yaitu sebagai berikut.

Pertama, media pembelajaran berupa media wayang melalui video pembelajaran yang dikembangkan layak diterapkan karena dapat meningkatkan minat anak usia dini dalam belajar. Media wayang melalui video pembelajaran layak diterapkan hal ini disebabkan karena dari segi kemenarikan serta kejelasan media. Kemenarikan media pembelajaran dapat meningkatkan minat siswa dalam belajar (Chang et al., 2021; Heo \& Toomey, 2020). Selain itu, materi yang disajikan pada video juga jelas sehingga memudahkan siswa dalam menggunakan media tersebut (Batubara \& Batubara, 2020; Febriani, 2017; Muskania et al., 2019). Media wayang melalui video pembelajaran ini dikemas dengan baik sehingga dapat menyampaikan informasi berupa kosakata bahasa inggris pada siswa dengan baik pula. Hal ini juga disesuaikan dengan teori yang menyatakan bahwa media pembelajaran yang dikemas dengan baik dapat membantu siswa dalam belajar (Andriyani \& Suniasih, 2021; Astuti \& Istiarini, 2020; D. K. Putri et al., 2020). Media media wayang melalui video pembelajaran dapat membuat pembelajaran menjadi menarik bagi anak usia dini. Hal ini menyebabkan siswa sangat senang belajar menggunakan media wayang melalui video pembelajaran ini.

Kedua, media pembelajaran berupa media wayang melalui video pembelajaran yang dikembangkan layak diterapkan karena dapat meningkatkan kosakata pada anak usia dini. Media video pembelajaran menyajikan materi kosakata yang menarik sehingga membuat siswa lebih mudah mengingat kosakata yang disajikan pada video. Media yang sesuai akan memudahkan siswa dalam memahami materi yang disajikan pada video (Purwantini, 2013; Rahmatia et al, 2021; Twiningsih \& Sayekti, 2020). Media audio visual sangat diminati anak-anak (Andriyani \& Suniasih, 2021; Muskania et al., 2019; Tegeh et al., 2019). Video pembelajaran yang dikembangkan ini dapat memudahkan anak dalam belajar kosakata bahasa Inggris dibandingkan dengan pembelajaran dengan metode yang konvensional. Media wayang ini selain dapat melatih aspek perkembangan bahasa juga terdapat aspek perkembangan lainnya yang dapat di stimulus diantaranya yaitu kognitif, sosial emosional fisik motorik, seni dan nilai moral agama anak.

Ketiga, media pembelajaran berupa media wayang melalui video pembelajaran yang dikembangkan layak diterapkan karena dapat menciptakan suasana belajar yang menyenangkan pada anak. Penggunaan media wayang melalui video pembelajaran ini membuat anak akan merasa senang dan tertarik dalam belajar karena akan diberikan kosakata bahasa Inggris dengan berbagai gambar wayang melalui video pembelajaran yang diberikan. Penggunaan media yang mudah dipahami oleh siswa akan menciptakan suasana belajar yang menyenangkan (Diyantari et al., 2020; Muyaroah \& Fajartia, 2017; Yendrita \& Syafitri, 2019). Selain itu anak dapat menggunakan media tersebut layaknya seperti bermain biasa, tidak seperti kegiatan pembelajaran yang formal. Dengan demikian anak dapat dengan mudah mengutarakan keinginannya. Melalui media wayang dapat meningkatkan kosakata bahasa Inggris anak, ini dibuktikan dengan penelitian yang telah dilakukan. Media yang menarik perhatian siswa membuat 
anak menjadi nyaman dalam belajar sehingga akan berpengaruh pada hasil belajar anak yang meningkat (Barnaba \& Asruddin, 2018; Shoffa, 2017; Susiani et al., 2013).

Temuan ini diperkuat dengan penelitian sebelumnya menyatakan bahwa media video sangat disukai oleh siswa sehingga dapat meningkatkan motivasi belajar siswa (Andriyani \& Suniasih, 2021; Muskania et al., 2019; Purwanti, 2015; Yildiz \& Yildiz, 2011). Penelitian lainnya juga menyatakan bahwa media wayang dapat meningkatkan kemampuan siswa (Pebri et al., 2017; Putra et al., 2019). Kelebihan media yang dikembangkan yaitu menggunakan media wayang sehingga juga dapat mengajarkan seni Indonesia. Selain itu media ini disajikan sesuai dengan karakteristik siswa yang memudahkan siswa dalam belajar. Kontribusi penelitian ini media wayang melalui video pembelajaran dapat meningkatkan motivasi siswa dalam belajar sehingga dapat meningkatkan kosakata bahasa Inggris pada siswa. Keterbatasan penelitian yaitu penelitian ini hingga uji validitas, tetapi tetap layak digunakan karena mendapatkan kategori sangat baik. Implikasi penelitian ini yaitu media dalam bentuk media wayang melalui video pembelajaran dapat dimanfaatkan guru untuk proses pembelajaran khususya dalam pembelajaran kosakata bahasa Inggris. Dengan menggunakan media wayang melalui video pembelajaran kegiatan belajar akan berjalan sesuai dengan yang diharapkan guru karena media yang digunakan menarik bagi anak dan dapat merangsang audio visual anak.

\section{SIMPULAN}

Berdasarkan hasil analisis data yang diperoleh dari ahli materi pelajaran dan media pembelajaran mendapatkan media wayang melalui video pembelajaran mendapatkan kualifikasi sangat tinggi. Dapat disimpulkan bahwa media wayang melalui video pembelajaran layak untuk anak usia dini dalam proses pembelajaran. Media wayang melalui video pembelajaran dapat membantu guru dalam menunjang pembelajaran sehingga anak dapat meningkatkan kemampuan kosakata bahasa Inggris.

\section{DAFTAR RUJUKAN}

Aisyah, A. (2017). Permainan Warna Berpengaruh Terhadap Kreativitas Anak Usia Dini. Jurnal Obsesi : Jurnal Pendidikan Anak Usia Dini, 1(2), 118. https://doi.org/10.31004/obsesi.v1i2.23.

Andriyani, N. L., \& Suniasih, N. W. (2021). Development Of Learning Videos Based On Problem-Solving Characteristics Of Animals And Their Habitats Contain in Science Subjects On 6th-Grade. Journal of Education, 5(1), 37-47. https://doi.org/10.23887/jet.v5i1.32314.

Astuti, R. F., \& Istiarini, R. (2020). Upaya Meningkatkan Kemampuan Membaca Permulaan AnakUsia 5-6 Tahun Melalui Media Puzzle di PAUD Flamboyan Sukasari Kota Tangerang. Ceria: Jurnal Program Studi Pendidikan Anak Usia Dini, 8(2), 31. https://doi.org/10.31000/ceria.v11i2.2338.

Barnaba, \& Asruddin. (2018). Peningkatan Penguasaan Kosakata Bahasa Inggris Melalui Media Anagram Dalam Metode Kooperatif Tipe Teams Games Tournament Improving the English Vocabulary Mastery Through Anagram Media in Cooperative Methods of Study Teams Games Tournament Type. Jurnal Prima Edukasia, 2(1), 80-89. https://doi.org/10.21831/jpe.v2i1.2646.

Batubara, H. H., \& Batubara, D. S. (2020). Penggunaan Video Tutorial untuk Mendukung Pembelajaran Daring di Masa Pandemi Virus Corona. Jurnal Madrasah Ibtidaiyah, 5(2), 78-84. https://doi.org/10. 31602/muallimuna.v5i2.2950.

Chang, T. Y., Hong, G., Paganelli, C., Phantumvanit, P., Chang, W. J., Shieh, Y. S., \& Hsu, M. L. (2021). Innovation of dental education during COVID-19 pandemic. Journal of Dental Sciences, 16(1), 1520. https://doi.org/10.1016/j.jds.2020.07.011.

Darihastining, S., Aini, S. N., Maisaroh, S., \& Mayasari, D. (2020). Penggunaan Media Audio Visual Berbasis Kearifan Budaya Lokal pada Anak Usia Dini. Jurnal Obsesi : Jurnal Pendidikan Anak Usia Dini, 5(2), 1594-1602. https://doi.org/10.31004/obsesi.v5i2.923.

Darmayasa, I. K., Jampel, N., \& Simamora, A. H. (2018). Pengembangan E-Modul Ipa Berorientasi Pendidikan Karakter Di Smp Negeri 1 Singaraja. Jurnal Edutech Undiksha, 6(1), 53-65. https://doi.org/10.23887/jeu.v6i1.20267.

Dewi, N. K., Tirtayani, L. A., \& Kristiantari, R. (2018). Pengaruh Metode Bermain Peran Terhadap Kemampuan Sosial Anak Kelompok B di Paud Gugus Anggrek, Kuta Utara. Jurnal Pendidikan Anak Usia Dini Universitas Pendidikan Ganesha, 6(1), 43-53. https://doi.org/10.23887/paud.v6i1.15090.

Dista. (2020). Manajemen Pendirian Taman Kanak-Kanak (Studi Kasus Di TK Fastrack Funschool Yogyakarta). Jurnal Pendidikan Anak Usia Dini Undiksha, 8(2), 101-111. https://doi.org/10.23887/paud.v8i2.22582.

Diyantari, I. A. K. D., Wiyasa, N., \& Manuaba, S. (2020). Model Snowball Throwing Berbantuan Media Pop 
Up Book Berpengaruh Terhadap Kompetensi Pengetahuan Ipa. Jurnal Ilmiah Pendidikan Profesi Guru, 3(1), 9-21. https://doi.org/10.23887/jippg.v3i1.26973.

Febriani, C. (2017). Pengaruh Media Video terhadap Motivasi Belajar dan Hasil Belajar Kognitif Pembelajaran IPA Kelas V Sekolah Dasar. Jurnal Prima Edukasia, 5(1), 11-21. https: //doi.org/10.21831/jpe.v5i1.8461.

Gunawan, G., Sahidu, H., Harjono, A., \& Suranti, N. M. Y. (2017). Efektivitas Penerapan Model Project Based Learning Berbantuan Media Virtual terhadap Kreativitas Fisika Peserta Didik. Jurnal Cakrawala Pendidikan, 36(2). https: //doi.org/10.21831/cp.v36i2.13514.

Hardiyanti, Y., Husain, M. S., \& Nurabdiansyah, N. (2018). Perancangan Media Pengenalan Warna Untuk Anak Usia Dini. JURNAL IMAJINASI, 2(2), 43. https://doi.org/10.26858/i.v2i2.9553.

Heo, M., \& Toomey, N. (2020). Learning with multimedia: The effects of gender, type of multimedia learning resources, and spatial ability. Computers and Education, 146, 103747. https://doi.org/10.1016/j.compedu.2019.103747.

Iswantiningtyas, V., \& Wulansari, W. (2018). Pengembangan Model Penilaian Pendidikan Karakter Anak Usia Dini. JPUD - Jurnal Pendidikan Usia Dini, 12(2), 361-370. https://doi.org/10.21009/jpud.122.17.

Kurnia, D., Taufiq, M., \& Silawati, E. (2018). Analisis Capaian Perkembangan Bahasa Anak Usia Dini Dalam Kegiatan Pembelajaran Dengan Metode Learning Based Resources. Cakrawala Dini: Jurnal Pendidikan Anak Usia Dini, 6(2). https://doi.org/10.17509/cd.v6i2.10520.

Marini, K. K. P. dan N. M. A. (2015). Penerapan Metode Bercerita Berbantuan Media Boneka Tangan Untuk Meningkatkan Keterampilan Berbicara Pada Anak Kelompok B3. E-Journal PG PAUD Universitas Pendidikan Ganesha: Jurusan Pendidikan Guru Pendidikan Anak Usia Dini, 3(1), 4. https://doi.org/10.23887/paud.v2i1.3239.

Melianti, E. R. (2020). Pengembangan Media Pembelajaran Berbasis Multimedia Interaktif Menggunakan Macromedia Director Pada Materi Usaha Dan Energi Kelas X. Jurnal Kumparan Fisika, 3(1), 1-10. https://doi.org/10.33369/jkf.3.1.1-10.

Moll-Khosrawi, P., Cronje, J. S., Zöllner, C., Kubitz, J. C., \& Schulte-Uentrop, L. (2021). Understanding How the Motivational Dimension of Learning is Influenced by Clinical Teaching in Medical Education: A Prospective Cohort Study. Annals of Medicine and Surgery, 65(February), 1-7. https://doi.org/10.1016/j.amsu.2021.102366.

Mundia Sari, K., \& Setiawan, H. (2020). Kompetensi Pedagogik Guru dalam Melaksanakan Penilaian Pembelajaran Anak Usia Dini. Jurnal Obsesi: Jurnal Pendidikan Anak Usia Dini, 4(2), 900. https://doi.org/10.31004/obsesi.v4i2.478.

Muskania, R. T., Badariah, S., \& Mansur, M. (2019). Pembelajaran Tematik Menggunakan Media Video Scribe Pada Siswa Kelas IV Sekolah Dasar. Elementary: Islamic Teacher Journal, 7(1). https: //doi.org/10.21043/elementary.v7i1.4927.

Mutakinati, L., Anwari, I., \& Yoshisuke, K. (2018). Analysis of students' critical thinking skill of middle school through stem education project-based learning. Jurnal Pendidikan IPA Indonesia, 7(1), 5465. https://doi.org/10.15294/jpii.v7i1.10495.

Muyaroah, \& Fajartia. (2017). Pengembangan Media Pembelajaran Berbasis Android dengan menggunakan Aplikasi Adobe Flash CS 6 pada Mata Pelajaran Biologi. Innovative Journal of Curriculum and Educational Technology, 6(2), 22-26. https://doi.org/10.15294/ijcet.v6i2.19336.

Nababan, R. S. (2016). Esensi dan Nilai Seni Poster Pagelaran Wayang Kulit Karya Gestisutis. Gelar : Jurnal Seni Budaya, 14(1), 27-37. https://doi.org/10.33153/glr.v14i1.1745.

Naharir, R. A., \& Dantes, N. (2019). Pengaruh Model Pembelajaran Course Review Horay Berbantuan Media Video Pembelajaran Terhadap Hasil Belajar Matematika Siswa Kelas V Semester II SD. Mimbar PGSD, 7(1). https://doi.org/10.23887/jjpgsd.v7i1.16975.

Pebri, Tegeh, \& Rahayu. (2017). Efektivitas Metode Bercerita Dengan Media Boneka Wayang Terhadap Kemampuan Bercakap-Cakap Anak Kelompok B Di TK Widya Sesana Sangsit 2016/2017. Journal Pendidikan Anak Usia Dini Undiksha, 5(3), 336-347. https://doi.org/10.23887/paud.v5i1.11557.

Poerwati, C. E., \& Cahaya, I. M. E. (2018). Project-Based Drawing Activities in Improving Social-Emotional Skills of Early Childhood. Jurnal Obsesi: Jurnal Pendidikan Anak Usia Dini, 2(2), 183. https://doi.org/10.31004/obsesi.v2i2.114.

Pramana, Tegeh, \& Agung. (2016). Pengembangan Video Pembelajaran IPA Kelas VI di SD N 2 Banjar Bali Tahun 2015/2016. Edutech Undiksha, 5(2). https://doi.org/10.23887/jeu.v4i2.7631.

Prameswari, N. K. (2018). Peningkatan Dalam Penggunaan Media Ular Tangga Mata Kuliah Pendidikan PKn SD Materi Strategi Pembelajaran Pada Kemampuan Kognitif Mahasiswa Semester 2 STKIP Bina Insan Mandiri Surabaya. Jurnal Bidang Pendidikan Dasar, 2(1), 9. https://doi.org/10.21067/jbpd.v2i1.2188. 
Purwanti, B. (2015). Pengembangan Media Video Pembelajaran. Jurnal Kebijakan Dan Pengembangan Pendidikan, 3(1), 42-47. https://doi.org/10.22219/jkpp.v3i1.2194.

Purwantini, J. (2013). Pengaruh Model Pembelajaran Tipe TGT Berbantuan Media Question Box Terhadap Hasil Belajar Matematika Siswa Kelas V SD. Jurnal Ilmiah, 1(1), 1-10. https://doi.org/10.23887/jjpgsd.v1i1.960.

Putra, A. T., Handarini, D. M., \& Ramli, M. (2019). Media Wayang Golek untuk Menumbuhkan Kesadaran Menyelesaikan Konflik secara Konstruktif bagi Siswa SMP. Jurnal Pendidikan: Teori, Penelitian, Dan Pengembangan, 4(11), 1478. https://doi.org/10.17977/jptpp.v4i11.13006.

Putri, D. K., Handayani, M., \& Akbar, Z. (2020). Pengaruh Media Pembelajaran dan Motivasi Diri terhadap Keterlibatan Orang Tua dalam Pendidikan Anak. Jurnal Obsesi : Jurnal Pendidikan Anak Usia Dini, 4(2), 649. https://doi.org/10.31004/obsesi.v4i2.418.

Putri, P. K., Achmad Hidayatullah, \& Shoffan Shoffa. (2020). Pengaruh Model Pembelajaran Kooperatif Tipe Two Stay Two Stray terhadap Hasil Belajar dan Minat Belajar. JUMLAHKU: Jurnal Matematika Ilmiah STKIP Muhammadiyah Kuningan, 6(1), 24-36. https://doi.org/10.33222/jumlahku.v6i1.885.

Rahmatia, R., Pajarianto, H., Kadir, A., Ulpi, W., \& Yusuf, M. (2021). Pengembangan Model Bermain Konstruktif dengan Media Balok untuk Meningkatkan Visual-Spasial Anak. Jurnal Obsesi : Jurnal Pendidikan Anak Usia Dini, 6(1), 47-57. https://doi.org/10.31004/obsesi.v6i1.1185.

Resti Aulia, B. N., \& Budiningsih, C. A. (2021). Tingkat Pemahaman Guru Taman Kanak-kanak di Lombok dalam Stimulasi Pengembangan Bahasa Anak Usia Dini. Jurnal Obsesi : Jurnal Pendidikan Anak Usia Dini, 5(2), 2259-2268. https://doi.org/10.31004/obsesi.v5i2.1082.

Sari, M. K. (2014). Pengaruh Metode Kooperatif Jigsaw Terhadap Prestasi Belajar Mata Pelajaran IPS Pada Siswa Kelas III. Jurnal Pendidikan Dasar Dan Pembelajaran, 4(2), 113-144. https: //doi.org/10.25273/pe.v4i02.313.

Shoffa, S. (2017). Implementasi Lesson Study Berbasis Karakter Pada Mata Kuliah Statistika Dasar Dengan Menggunakan Media "Gabuz." Jurnal Pendidikan Dan Ilmu Pengetahuan, 14(2), 45-65. https://doi.org/10.30651/didaktis.v14i1.50.

Stoica, A. M., \& Roco, M. (2013). The Role of the Emotional Intelligence in Kindergarden Children's Development. Procedia - Social and Behavioral Sciences, 78(1), 150-154. https://doi.org/10.1016/j.sbspro.2013.04.269.

Sudiarta, I. G. P., \& Sadra, I. W. (2016). Pengaruh Model Blended Learning berbantuan Video Animasi Terhadap Kemampuan Pemecahan Masalah dan Pemahaman Konsep Siswa. Jurnal Pendidikan Dan Pengajaran, 49(2), 48. https://doi.org/10.23887/jppundiksha.v49i2.9009.

Sunismi. (2015). Developing Guided Discovery Learning Materials Using Mathematics Mobile Learning Application As An Alternative Media For The Students Calculus II. Cakrawala Pendidikan, 34(3), 334-346. https://doi.org/10.21831/cp.v3i3.7340.

Suprihatin, E. W., \& Pratamawati, D. (2019). Conservation Strategy in Preserving The Local Image Existence of Wayang Topeng. Harmonia: Journal of Arts Research and Education, 19(2), 179-184. https://doi.org/10.15294/harmonia.v19i2.24005.

Susiani, P. E., Pudjawan, K., \& Renda, N. T. (2013). Penerapan Metode Role Playing Berbantuan Media Boneka Gambar Untuk Meningkatkan Kemampuan Bahasa Indonesia Anak Kelompok B TK Satya Kumara. Jurnal Pendidikan Anak Usia Dini Undiksha, 1(1). https://doi.org/10.23887/paud.v1i1.1138.

Susmiati, E. (2020). Meningkatkan Motivasi Belajar Bahasa Indonesia Melalui Penerapan Model Discovery Learning dan Media Video Dalam Kondisi Pandemi Covid-19 bagi Siswa SMPN 2 Gangga. Jurnal Paedagogy, 7(3), 210. https://doi.org/10.33394/jp.v7i3.2732.

Swastrini, K. C., Antara, P. A., \& Tirtayani, L. A. (2016). Penerapan Bermain Ular Tangga Untuk Meningkatkan Kemampuan Kerjasama Kelompok B1 di TK Widya Sesana Sangsit. Pendidikan Anak Usia Dini, 4(2). https://doi.org/10.23887/paud.v4i2.7764.

Tegeh, Simamora, \& Dwipayana. (2019). Pengembangan Media Video Pembelajaran Dengan Model Pengembangan 4D Pada Mata Pelajaran Agama Hindu. Jurnal Mimbar Ilmu, 24(2), 158-166. https: //doi.org/10.23887/mi.v24i2.21262.

Twiningsih, A., \& Sayekti, T. (2020). Peningkatan Keterampilan Berhitung Siswa Melalui Media Kotak Ajaib Berbasis Stem Pada Materi Konsep Penjumlahan. Jurnal Pendidikan Dasar, 11(1). https://doi.org/doi.org/10.21009/JPD.011.02.

Umbara, Sujana, I. W., \& Negara, I. G. A. O. (2020). Model Pembelajaran Problem Based Learning Berbantuan Media Gambar Seri BerpengaruhTerhadap Kompetensi Pengetahuan IPS Siswa. Jurnal Mimbar Ilmu, 25(2), 174-186. https://doi.org/10.23887/mi.v25i2.25154.

Widnyana, I. G., Sujana, I. W., \& Putra, I. K. A. (2017). Pengaruh Model Pembelajaran Role Playing Berbasis 
Tri Hita Karana Terhadap Kompetensi Pengetahuan Ips Kecamatan Denpasar Timur Tahun Pelajaran 2016 / 2017. MIMBAR PGSD Undiksha, 5(2), 1-10. https://doi.org/10.23887/jjpgsd.v5i2.11995.

Widodo, H. (2016). otret Pendidikan Di Indonesia Dan Kesiapannya Dalam Menghadapi Masyarakat Ekonomi Asia (MEA). Cendekia: Journal of Education and Society, 13(2), 293. https://doi.org/10.21154/cendekia.v13i2.250.

Yendrita, Y., \& Syafitri, Y. (2019). Pengaruh Penggunaan Media Video Pembelajaran terhadap Hasil Belajar Biologi. BIOEDUSAINS: Jurnal Pendidikan Biologi Dan Sains, 2(1), 26-32. https://doi.org/10.31539/bioedusains.v2i1.620.

Yildiz, S., \& Yildiz, E. (2011). A study on pc - Video games in terms of the space awareness from childhood to youth. Procedia - Social and Behavioral Sciences, 28, 796-800. https://doi.org/10.1016/j.sbspro.2011.11.145.

Yuliani, Antara, \& Magta. (2017). Pengaruh Video Pembelajaran Terhadap Kemampuan Berhitung Permulaan Anak Kelompok B Di Taman Kanak-Kanak. Jurnal Pendidikan Anak Usia Undiksha, 5(1), 96-106. https://doi.org/10.23887/paud.v5i1.11309.

Yuniarni, Sari, \& Atiq. (2020). Pengembangan Multimedia Interaktif Video Senam Animasi Berbasis Budaya Khas Kalimantan Barat. Jurnal Obsesi: Jurnal Pendidikan Anak Usia Dini, 4(1). https://doi.org/10.31004/obsesi.v4i1.331.

Yusnia, Y. (2019). Penggunaan Media Video Scribe Dalam Pembelajaran Literasi Sains Untuk Mahasiswa PGPAUD. Cakrawala Dini: Jurnal Pendidikan Anak Usia Dini, 10(1), 71-75. https://doi.org/10.17509/cd.v10i1.17436. 